\title{
The Correlation Between The Quality of Health Services And The Involvement of Re-Visit Patients in Public Healthcare
}

\author{
Menik Kustriyani' ${ }^{1}$, Suci Andyana², Rahayu Winarti ${ }^{3}$
}

1,2,3 Stikes Widya Husada Semarang

\begin{tabular}{|c|c|}
\hline Article Info & Abstract \\
\hline $\begin{array}{l}\text { Article History: } \\
\text { Accepted Oct 18th } 2018 \\
\text { Key words: } \\
\text { Health Service Quality } \\
\text { Re-visit Rate }\end{array}$ & $\begin{array}{l}\text { Background : Healthcare quality should be improved to give patients } \\
\text { satisfaction, that will lead them to use the service again and recommend } \\
\text { the health center to the other people. The quality also affects the patient } \\
\text { revisit rate. Good service and quality have to fulfill five dimensions of } \\
\text { service quality, namely responsiveness, assurance, tangible, empathy, and } \\
\text { reliability. This research is conducted to acknowledge the relation between } \\
\text { health care service quality and out-patient revisit rate in Mijen Community } \\
\text { Health Center, Semarang. } \\
\text { Methods : This research is analytical quantitative research. The method } \\
\text { used in this research is cross-sectional design. The sample was selected } \\
\text { using purposive sampling technique, with a total sample of } 74 \text { respondents } \\
\text { and using informed consent for the filled in by respondents. The data was } \\
\text { taken by using a questionnaire with the rank spearman trial analysis } \\
\text { method. } \\
\text { Result : } 58.1 \text { respondents state that the healthcare service quality is good. } \\
77.0 \text { respondents stated that they are willing to revisit Mijen Community } \\
\text { Health Center, Semarang. The result of rank spearman statistic trial shows } \\
\text { that there is a correlation between health care service quality and out- } \\
\text { patient revisit rate in Mijen Community Health Center, Semarang (p=0,000) } \\
\text { which is lower than } \alpha=0 \text {, } 05 \text {. } \\
\text { Conclusion : The better healthcare service quality given to the patient, the } \\
\text { higher patient revisit rate in Mijen Community Health Center, Semarang. }\end{array}$ \\
\hline
\end{tabular}

\section{PENDAHULUAN}

Pelayanan kesehatan pasien rawat jalan sekarang ini yaitu salah satu pelayanan kesehatan yang menjadi perhatian utama. Hal disebabkan oleh masyarakat yang kecenderungan mencari pelayanan pengobatan yang praktis sekali berkunjung dan pada hari itu juga mendapatkan pelayanan kesehatan yang lengkap (one day care). Maka dari itu managemen dari institusi pelayanan kesehatan menyadari bahwa menetapkan posisi yang kuat di dalam pasar rawat jalan adalah hal yang terpenting demi kelangsungan institusi pelayanan kesehatan. Managemen rawat jalan dengan demikian harus mampu

Corresponding author:

Menik Kustriyani

menikkustriyani@gmail.com

Media Keperawatan Indonesia, Vol 1 No 3, October 2018

e-ISSN: 2615-1669

DOI:10.26714/mki.1.3.2018.24-31 
memberikan pelayanan kesehatan yang berkualitas sehingga dapat mempertahankan pelanggan yang sudah ada (Hapsari, 2006 dalam Hamidiyah, 2016).

Pandangan pasien atau masyarakat saat ini sangat penting karena pasien yang merasakan puas akan mematuhi pengobatan serta mempunyai minat untuk melakukan kunjungan ulang kembali. Dimensi mutu pelayanan kesehatan yang berhubungan dengan terpuaskannya pasien atau masyarakat bisa mempengaruhi kesehatan serta kesejahteraan pada masyarakat. Karena minat kunjungan kembali masyarakat di pengaruhi oleh pengalaman terhadap pelayanan yang di berikan sebelumnya sehingga masyarakat lebih sering menganggap dimensi efektifitas, akses, hubungan antara manusia, kesinambungan, serta kenyamanan sebagai suatu dimensi mutu pelayanan kesehatan yang sangat penting (Pohan, 2017).

Data awal yang di peroleh di Puskesmas Mijen Kota Semarang yang dilakukan pada hari Senin tanggal 27 Maret 2018. Didapatkan data kunjungan pasien rawat jalan dari bulan Maret adalah 3340, April sebanyak 3330, Mei sebanyak 3199, dan juni 2438 pasien. Dapat diketahui berdasarkan wawancara yang dilakukan pada 15 responden terdapat 3 responden $(20,0 \%)$ menyatakan puas terhadap pelayanan dan berminat melakukan kunjungan ulang, terdapat 5 responden (33, 3\%) menyatakan cukup puas terhadap pelayanan dan berminat melakukan kunjungan ulang dan sisanya 7 responden $(46,7 \%)$ menyatakan tidak puas terhadap pelayanan dan berminat melakukan kunjungan ulang, ketidakpuasan disebabkan karena keadaan ruangan Puskesmas yang kurang bersih, kurang nya tempat pembuangan sampah, kursi di ruang tunggu yang kurang, antrian yang terlalu lama baik antrian obat maupun giliran serta pemeriksaan dokter yang terlalu tergesagesa sehingga keluhan pasien tidak sepenuhnya tersampaikan.

Mutu pelayanan puskesmas merupakan aspek penting yang dapat memberikan kepuasan terhadap pasien, sehingga dapat menjadi pendorong kepada pasien sehingga berpengaruh terhadap minat kunjungan ulang pasien untuk kembali memanfaatan pelayanan kesehatan yang disediakan, karena minat perilaku pasien untuk memakai jasa dari pemberi jasa yang sama sangat dipengaruhi oleh pengalaman kepuasan terhadap mutu kualitas pelayanan yang diberikan sebelumnya. Sehingga atas latar belakang tersebut peneliti ingin mengetahui "Apakah ada Hubungan Mutu Pelayanan Kesehatan Dengan Minat Kunjungan Ulang Pasien Rawat Jalan di Puskesmas Mijen Kota Semarang " 
METODE

Penelitian ini menggunakan metode kuantitatif analitik dan pendekatan yang digunakan adalah cross sectional. Tempat penelitian ini adalah Penelitian ini dilakukan di Rawat Jalan Puskesmas Mijen Kota Semarang pada bulan Agustus 2018. Populasi pada penelitian ini pada bulan Juni 2438 pasien pada tahun 2018 dan rata - rata pasien rawat jalan yang datang setiap hari nya 90 pasien rawat jalan. Sampel dalam penelitian ini adalah 74 pasien Rawat Jalan di Puskesmas Mijen Kota Semarang.. Alat ukur yang digunakan dalam penelitian adalah kuesioner. Alat ukur terdiri dari 3 kategori, yaitu: karakteristik responden, mutu pelayanan, dan minat kunjungan ulang.
HASIL

Responden dalam penelitian ini berjumlah 74 pasien rawat jalan. Responden berdasarkan umur, Dewasa awal (17 - 25 tahun) 17,6\%, dewasa tengah (26- 35 tahun) 31\% dan dewasa akhir (36- 45 tahun) 51,4\%. Pendidikan responden Perguruan Tinggi 4,1\%, SMA 48,6\%, SMP 25,7 \%, SD 16,2 \% dan Tidak tamat 5,4\%.

Mutu pelayanan kesehatan Puskesmas Mijen Agustus 2018 Baik sebanyak 43 responden (58,1\%), cukup baik 24 reponden $(32,4 \%)$ dan kurang baik 7 responden (9,5\%). Minat kunjungan ulang Puskesmas Mijen Agustus 2018 responden yang sangat minat sebanyak 57 (77\%), cukup minat $14(18,9 \%)$ dan tidak minat 3 $(4,1 \%)$.

Tabel 1. Hubungan Mutu Pelayanan Kesehatan Dengan Minat Kunjungan Ulang Pasien Rawat Jalan

\begin{tabular}{|c|c|c|c|c|c|c|c|c|c|}
\hline \multicolumn{9}{|c|}{ Minat Kunjungan Ulang } & \multirow{3}{*}{$\mathbf{p}$} \\
\hline $\begin{array}{c}\text { Mutu Pelayanan } \\
\text { Kesehatan }\end{array}$ & \multicolumn{2}{|c|}{$\begin{array}{l}\text { Tidak } \\
\text { Minat }\end{array}$} & \multicolumn{2}{|c|}{$\begin{array}{l}\text { Cukup } \\
\text { Minat }\end{array}$} & \multicolumn{2}{|c|}{$\begin{array}{c}\text { Sangat } \\
\text { Minat }\end{array}$} & \multirow{2}{*}{$\begin{array}{c}\text { Total } \\
\mathbf{F}\end{array}$} & \multirow[t]{2}{*}{$\boldsymbol{r}$} & \\
\hline & $\mathbf{F}$ & $\%$ & $\mathbf{F}$ & $\%$ & $\mathbf{F}$ & $\%$ & & & \\
\hline Kurang Baik & 1 & 1,4 & 3 & 4,1 & 3 & 4,1 & 7 & \multirow{4}{*}{0,816} & \multirow{4}{*}{0,000} \\
\hline Cukup Baik & 2 & 2,7 & 11 & 14,9 & 11 & 14,9 & 24 & & \\
\hline Baik & 0 & 0,0 & 0 & 0,0 & 43 & 58,1 & 43 & & \\
\hline Jumlah & 3 & 4,1 & 14 & 19 & 57 & 77,1 & 74 & & \\
\hline
\end{tabular}

\section{PEMBAHASAN}

Mutu pelayanan adalah terpenuhinya standar dan pelanggan memiliki presepsi yang baik terhadap layanan tersebut karena harapannya dapat terpenuhi. Mutu pelayanan menjadi fokus utama dalam memberikan pelayanan kesehatan atau keperawatan. Berdasarkan hasil analisis kuesioner didapatkan hasil bahwa kontribusi terendah dari kelima dimensi kualitas pelayanan kesehatan yang pertama 
yaitu berada pada dimensi responsivennes (ketanggapan) dimana pasien masih membutuhkan waktu yang lama untuk mendapatkan pelayanan Dimensi yang kedua yaitu dimensi empathy (empati), nilai terendah dari hasil analisis kuesioner terhadap dimensi emphaty (empati) adalah perawat belum bisa memberikan perhatian kepada pasien dengan baik, kontribusi terendah yang ketiga yaitu berada pada dimensi tangiable (bukti fisik).

Dimana nilai hasil terendah dari analisis kuesioner di Puskesmas Mijen Kota Semarang dikarenakan tenaga medis maupun non medis berpenampilan kurang rapi dan tidak tersedianya tempat duduk yang cukup untuk pasien yang menunggu antrian, sedangkan kontribusi terendah yang keempat yaitu dimensi assurance (keyakinan) , dimana responden menilai bahwa perawat kurang memiliki pengetahuan keperawatan dalam menjalankan tugas sebagai perawat serta perawat masih kurang baik dalam memberikan jaminan perawatan sehingga pasien kurang percaya terhadap perawat. dimensi yang kelima yaitu dimensi reliability (kehandalan) dimana nilai terendah dari hasil analisis kuesioner terhadap dimensi reliability adalah perawat masih kurang teliti dan peduli terhadap penanggulangan masalah pasien.
Berdasarkan hasil penelitian tentang karakteristik umur responden pasien rawat jalan mayoritas pada kategori usia (36 - 45 tahun) dengan jumlah 38 responden (51,4\%), pada kelompok umur 26-35 tahun sebanyak 23 responden (31,0\%), pada kelompok umur 17-25 tahun sebanyak 13 responden $(17,6 \%)$, hal ini sejalan dengan penelitian Masdiah Damanik (2014) menunjukkan bahwa usia (36 - 45 tahun) dengan jumlah 32 responden (40,0\%).

Usia 36 - 45 tahun merupakan usia dewasa akhir atau pra lansia, pada tahapan ini akan mengalami berbagai penurunan daya tahan tubuh/kesehatan dan berbagai tekanan psikologis. Dengan demikian pada usia dewasa akhir atau pra lansia lebih rentang mengalami banyak keluhan dibandingakan dengan umur sebelumnya atau usia sebelum tahapan dewasa akhir. Hal tersebut yang menyebabkan rata - rata usia tahapan dewasa akhir atau pra lansia sering berkunjung di layanan kesehatan (Puskesmas). Pelayanan kesehatan yang berkualitas menjadi lebih penting untuk diperhatikan karena apabila ia mendapatkan pelayanan yang memuaskan, maka akan memiliki presepsi yang baik terhadap mutu pelayanan sehingga berpotensi untuk kembali memeriksakan kesehatannya dan tidak menutup kemunkinan ia akan membawa keluarganya untuk memilih tempat pelayanan kesehatan 
yang terbaik untuk diri dan keluarganya (Hurlock, 2015).

Di dapatkan juga bahwa sebagian besar responden berdasarkan jenis kelamin dapat diketahui berjenis kelamin perempuan sebanyak 53 responden (71,6\%), dan lakilaki sebanyak 21 responden (28,4\%). Hal ini sejalan dengan penelitian Putra (2017) bahwa jenis kelamin responden terbanyak adalah perempuan 32 responden (45\%). Tubuh perempuan dan pria memiliki karakter yang berbeda dengan penurunan daya tahan tubuh/kesehatan tubuh wanita lebih rentang mengalami banyak keluhan dibandingakan dengan pria. Alhasil, akan ada perbedaan wanita dimana tubuh lebih merasakan sakit yang tak tertahankan dari pada pria dalam mengalami berbagai keluhan di setiap harinya. Terjadi karena proses hormonal pada tiap jenis kelamin berbeda-beda, tetapi hal tersebut tidaklah berlaku dalam beberapa kasus seperti penelitian terhadap osteoporosis, depresi pada pria ataupun wanita (IDAI,2016).

Berdasarkan hasil penelitian masih terdapat responden yang tidak minat sebanyak $(4,1 \%)$ dan cukup minat sebanyak ( $18,9 \%)$ akan pelayanan di Puskesmas Mijen Kota Semarang. Hal ini disebabkan karena pasien merasa prosedur pelayanan kesehatan yang kurang baik, waktu tunggu untuk mendapatkan pelayanan yang lama, kurangnya keramahan tenaga kesehatan serta komunikasi tentang komunikasi tentang informasi yang diberikan terkadang kurang jelas. Oleh karena itu permasalahan tersebut harus dilakukan evaluasi sehingga pelayanan kesehatan menjadi berkualitas dan membuat pasien berminat melakukan kunjungan ulang untuk menggunakan pelayanan kesehatan di Puskesmas Mijen Kota Semarang. Hal ini sejalan dengan penelitian yang di lakukan oleh Hendra Hasbi (2015) sebanyak 71 responden $(84,7 \%)$ berminat untuk kembali mendapatkan pelayanan.

Sejalan dengan hasil penelitian Masnunah pada responden yang sangat puas, terdapat 38 responden yang berminat berobat kembali di RSD Kalisat Jember, secara keseluruhan responden merasa sangat puas pada dimensi jaminan dan cenderung berobat kembali. Kompetensi sumber daya manusia, keramahan dalam berkomunikasi dan kredibilitas merupakan unsur dimensi jaminan yang mempengaruhi kepuasan pasien (Masnunah, 2017)

Masih terdapat responden yang tidak minat sebanyak $(4,1 \%)$ dan cukup minat sebanyak ( $18,9 \%)$ akan pelayanan di Puskesmas Mijen Kota Semarang. Hal ini disebabkan karena pasien merasa prosedur pelayanan kesehatan yang kurang baik, waktu tunggu untuk mendapatkan pelayanan yang lama, kurangnya 
keramahan tenaga kesehatan serta komunikasi tentang komunikasi tentang informasi yang diberikan terkadang kurang jelas. Oleh karena itu permasalahan tersebut harus dilakukan evaluasi sehingga pelayanan kesehatan menjadi berkualitas dan membuat pasien berminat melakukan kunjungan ulang untuk menggunakan pelayanan kesehatan di Puskesmas Mijen Kota Semarang.

Minat adalah dorongan pada dalam diri seseorang atau faktor yang dapat menimbulkan ketertarikan atau perhatian secara efektif, sehingga menyebabkan terpilihnya suatu objek atau kegiatan yang menguntungkan, menyenangkan serta lama-kelamaan akan mendatangkan dalam dirinya kepuasan. Minat sesungguhnya lebih menetap dengan kata lain bertahan lama dalam diri seseorang, merupakan kecenderungan hati yang lebih tinggi terhadap sesuatu hal, yang pada dasarnya minat tidak timbul dengan sendiri, melainkan adanya unsur kebutuhan (Susanto, 2013)

Pendidikan termasuk dalam pembelajaran, pengetahuan, keterampilan dan kebiasaan sekelompok orang yang di turunkan dari satu generasi ke generasi beikutnya melalui pengajaran, pelatihan, atau penelitian. Pendidikan sering terjadi di bawah bimbingan orang lain, tetapi juga memungkinkan secara otodidak, semakin tinggi pendidikan kita maka semakin banyak juga wawasan yang kita dapat, dari cara bersikap kepada orang yang baru di kenal ataupun dari cara kita menilai sesuatu hal yang sering kita jumpai di dalam masyarakat.

Hasil uji statistik Rank Spearman didapatkan nilai $\mathrm{p}(\mathrm{Rho})=0,816$ dan $\mathrm{p}$ value $=0,000 \leq 0,05$. Hasil menunjukkan bahwa ada hubungan yang signifikan antara Mutu Pelayanan Kesehatan Dengan Minat Kunjungan Ulang Pasien Rawat Jalan di Puskesmas Mijen Kota Semarang. Diketahui bahwa responden yang menyatakan mutu pelayanan kesehatan baik cenderung merasa senang dengan minat kunjungan ulang pasien sebanyak 57 responden ( 77,0\%), karena antara mutu pelayanan kesehatan dengan minat kujungan ulang pasien dapat disimpulkan bahwa mutu pelayanan berpengaruh positif dengan minat kunjungan ulang pasien hal ini menunjukkan bahwa semakin besar mutu pelayanan maka minat kunjungan ulang akan semakin besar.

Penelitian ini sejalan dengan penelitian Lestari, menjelaskan bahwa terdapat pengaruh positif signifikan kualitas layanan terhadap kepuasan dan kualitas layanan terhadap minat kunjungan ulang pasien (Lestari, 2017). Hasil penelitian Sewow menjelaskan bahwa faktor sarana prasarana, lokasi, kecepatan dan 
kemudahan pelayanan rumah sakit, pelayanan personal, dengan pemanfaatan kembali pelayaan rumah sakit Tompaso baru dan kecepatan dan kemudahan adalah variabel yang paling dominan dengan nilai wald 3,402 dibandingkan dengan variabelvariabel lain terhadap di rumah sakit Cantia Tompasobaru. Faktor kecepatan dan kemudahan pelayanan rumah sakit lebih baik dibandingkan dengan faktor yang lain.

Penelitian lain yang mendukung hasil penelitian di atas adalah penelitian Chintia Devi (2016), dengan menggunakan uji chisquare dengan kemaknaan yang tetap $\alpha \leq$ 0,05 nilai yang didapatkan hasil $\mathrm{P}$ value $=$ 0,013 bahwa ada hubungan mutu pelayanan dengan minat kunjungan ulang pasien rawat jalan di Puskesmas Bogor. Pelayanan kesehatan yang bermutu merupakan pelayanan kesehatan yang dapat memuaskan setiap pemakai jasa pelayanan kesehatan sesuai dengan tingkat kepuasannya rata-rata masyarakat, serta dalam penyelenggaraanya sesuai dengan standar serta kode etik yang sudah ditetapkan.

Mutu pelayanan dalam kesehatan merupakan derajat dipenuhinya kebutuhan masyarakat ataupun perorangan terhadap asuhan kesehatan yang sesuai dengan standar. Profesi yang baik dengan pemanfaatan sumber daya secara wajar, efisen, efektif dalam keterbasan kemampuan

pemerintah

serta diselenggarakan secara aman dan memuaskan pelanggan sesuai dengan norma dan etika yang baik akan membuat minat pada sesorang muncul karena adanya dorongan pada dalam diri seseorang atau faktor yang dapat menimbulkan ketertarikan atau perhatian secara efektif, sehingga menyebabkan terpilihnya suatu objek atau kegiatan yang menguntungkan, menyenangkan serta lama-kelamaan akan mendatangkan dalam dirinya kepuasan. Minat sesungguhnya lebih menetap dengan kata lain bertahan lama dalam diri seseorang (Susanto, 2013)

\section{SIMPULAN}

Responden yang menyatakan bahwa mutu pelayanan kesehatan di Puskesmas Mijen Kota Semarang dengan presentase tertinggi ada pada mutu pelayanan kesehatan baik sejumlah 43 responden (58,1\%), terdapat tiga dimensi mutu pelayanan yang bernilai rendah yaitu dimensi ketanggapan (responsivenes), empati (empathy) dan bukti fisik (tangible). Responden yang menyatakan bahwa minat terhadap pelayanan kesehatan di Puskesmas Mijen Kota Semarang dengan presentase tertinggi ada pada sangat minat terhadap pelayanan kesehatan sejumlah 57 responden $(77,0 \%)$.

Ada hubungan antara mutu pelayanan kesehatan dengan minat kunjungan ulang 
pasien rawat jalan di Puskesmas Mijen Kota

Semarang, dibuktikan dengan nilai r- 0,816

dan $p=0,000$ yang berarti lebih kecil dari $\alpha_{\alpha}^{\prime}=0,05(\mathrm{p}<\alpha)$.

\section{REFERENSI}

Afifah, Kunik. (2017). Hubungan Mutu Pelayanan Kesehatan Dengan Minat Kunjungan Ulang Pasien Di Puskesmas Cangkringan Sleman. Skripsi. Fakultas ilmu keperawatan. Sekolah Tinggi jenderal Ahmad Yani yogyakarta. Diakses 2017.

Damanik, Masidah. (2014). Hubungan Presepsi Pasien Tentang Mutu Pelayanan Dengan Minat Pemanfaatan Ulang Pelayanan Rawat Jalan Di Puskesmas Sewon 1 Bantul. Skripsi. Fakultas ilmu keperawatan. Sekolah Tinggi jenderal Ahmad Yani yogyakarta. Diakses 2017

Hasbi, Hendra. (2015). Hubungan Persepsi Pasien Tentang Mutu Pelayanan Dengan Pemanfaatan Ulang Pelayanan Rawat Jalan Di Puskesmas Poncol Semarang
Hurlock, Elizabeth. (2015). Psikologi Perkembangan: Suatu Pendekatan Sepanjang Rentang Kehidupan. Jakarta: Erlangga

Ikatan Dokter Anak Indonesia (IDAI). (2016). Buku Ajar Respirologi Anak. Jakarta: Badan Ikatan Dokter Anak Indonesia.

Lestari, dkk. (2017). Pengaruh Kualitas Layanan terhadap Kepuasan dan Minat Kunjungan Ulang Pasien di Wilayah Kerja Puskesmas Mandai Kabupaten Maros. Jurnal Ilmiah Kesehatan Diagnosis. Vol.11, No.4

Masnunah, dkk. (2017). Hubungan Indeks Kepuasan Pasien Tentang Mutu Pelayanan Dimensi Jaminan dengan Minat Berobat Kembali di Poli Interna RSD Kalisat Jember. E-Journal Pustaka Kesehatan. Vol.5. No.2 Mei 2017

Pohan, Imbalo. (2017). Jaminan Mutu Layanan Kesehatan Dasar-Dasar Pengertian Dan Penerapan. Jakarta: EGC.

Sewow, dkk. (2018). Faktor - faktor yang berhubungan dengan Loyalitas Pasien Pelayanan Rawat Jalan di Rumah Sakit Cantia Tompaso Baru. Ejournalhealth.Vol.6, No.2

Susanto, Ahmad. (2013). Teori Belajar Dan Pembelajaran Di Sekolah Dasar. Jakarta: Prenada Media 